\title{
KONTRIBUSI KOMPETENSI MANAJERIAL KEPALA SEKOLAH DAN PERAN KOMITE SEKOLAH TERHADAP KETERSEDIAAN SARANA LABOR IPA PADA SMPN DI KOTA SAWAHLUNTO
}

\author{
Daswirman \\ SMPN 7 Kota Sawahlunto, Sumatera Barat \\ Korespondensi: Dusun Ladang Laweh - Talago Gunung, Kec. Barangin - Kota Sawahlunto \\ e-mail: daswirman044@gmail.com
}

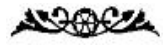

\begin{abstract}
The background of this study is the lack of good Managerial Competence Principal and lack Role of School Committees, resulting in unmet availability of Labor Science at secondary schools in Sawablunto. The purpose of this study is to reveal how much the contribution of Managerial Competence Principal and Role of School Committees to the availability of Labor Science at secondary schools in Sawablunto. This study uses a quantitative method that describes the condition of the field as it is to look at the various issues that arise today The study hypothesis in the study are: (1) The presence of Managerial Competence Principal contribution to the availability of Labor Science at secondary schools in Sawablunto. (2) The presence contributions Role of School Committees to the availability of Labor Science at secondary schools in Sawablunto. (3) The presence contributions Managerial Competence Principal and Role of School Committees to the availability of Labor Science at secondary schools in Sawablunto. The population of this research is all a science teacher at SMPN in Sawablunto totaling 30 persons Number samples are 30 people. The samples in this study by using the "Total Sampling". From these results, it was revealed that: (1) Managerial Competence Principal contribute positively and significantly to the availability of Labor Science at secondary schools in Sawablunto, by 27,1\% (2) the role of the School Committee to contribute positively and significantly to the availability of Labor science at secondary schools in Sawablunto, availability of Labor science at secondary schools in Sawablunto is determined by the role of the School Committee of 26.2\%. (3) Managerial Competence Principal (X1) and variable Role of School Committees (X2) contributed positively and significantly to the availability of Labor Science at secondary schools in Sawablunto, and the availability of Labor Science at secondary schools in Sawablunto is determined by the Managerial Competence Principal and Role of School Committees jointly at $39.5 \%$.
\end{abstract}

Keywords: Competence Managerial, Committee School, Labor IPA

\section{PENDAHULAN}

Keberadaan Komite Sekolah harus bertumpu pada landasan partisipasi masyarakat dalam meningkatkan kualitas pelayanan dan hasil pendidikan di sekolah. Oleh karena itu, pembentukannya harus memperhatikan pembagian peran sesuai posisi dan otonomi yang ada.

Menurut Kemendiknas (Nomor 004/U/2002 tanggal 2 April 2002) peran yang dijalankan Komite Sekolah adalah sebagai berikut: 
a) Pemberi pertimbangan (advisory agency) dalam penentuan dan pelaksanaan kebijakan pendidikan di satuan pendidikan.

b) Pendukung (supporting agency), baik yang berwujud finansial, pemikiran, maupun tenaga dalam penyelenggaraan pendidikan di satuan pendidikan.

c) Pengontrol (controlling agency) dalam penyelenggaraan kegiatan di satuan pendidikan.

d) Mediator antara pemerintah (eksekutif) dengan masyarakat di satuan pendidikan

Menurut Depdiknas (2002: 26) Laboratorium IPA merupakan tempat untuk mengaplikasikan teori keilmuan, pengujian teoritis, pembuktian uji coba, penelitian, dan sebagainya dengan menggunakan alat bantu yang menjadi kelengkapan dari fasilitas dengan kuantitas dan kualitas yang memadai.

Kepala sekolah adalah guru yang diberi tugas tambahan sebagai kepala sekolah untuk memimpin penyelenggaraan pendidikan dan upaya meningkatkan mutu pendidikan di sekolah. Guru yang diberi tugas tambahan sebagai kepala sekolah perlu senantiasa meningkatkan kemampuan, pengabdian, dan kreativitasnya, agar dapat melaksanakan tugas secara profesional. Guru Pegawai Negeri Sipil di lingkungan Departemen Pendidikan Nasional dapat diberi tugas sebagai Kepala Sekolah yang diselenggarakan oleh Departemen maupun Kepala Sekolah dipekerjakan di sekolah yang diselenggarakan oleh masyarakat.

Menurut Bafadal (2006: 33) Tugas Pokok Kepala Sekolah adalah mengelola penyelenggaraan kegiatan pendidikan dan pembelajaran di sekolah. Secara lebih operasional tugas pokok kepala sekolah mencakup kegiatan menggali dan mendayagunakan seluruh sumber daya sekolah secara terpadu dalam kerangka pencapaian tujuan sekolah secara efektif dan efisien.

Laboratorium merupakan salah satu sarana prasarana yang harus disediakan oleh penyelenggara sekolah untuk menunjang kegiatan belajar mengajar. Hal tersebut tercantum dalam PP no. 19 tahun 2005 tentang Standar Nasional Pendidikan yang dijelaskan pada bab 2 pasal 2 tentang lingkup Standar nasional Pendidikan.

Namun pada kenyataan yang dijumpai keberadaan komite sekolah belum dapat dirasakan sesuai dengan apa yang diharapkan, kita masih menjumpai hubungan yang kurang harmonis antara sekolah dengan orang tua, dimana sebagian orang tua kurang memberikan perhatiannya pada apa yang telah disepakati bersama antara sekolah dengan komite sekolah, bukan karena mereka tidak tahu akan kesepakatan yang telah dibuat, namun karena kurangnya kesadaran untuk berpartisipasi.

Berdasarkan studi pendahuluan di SMPN se-kota Sawahlunto tentang Kompetensi Manajerial ditemukan bahwa kepala sekolah masih belum mampu dalam mengelola sarana prasarana, Masih kurangnya ketersediaan sarana Labor IPA, belum terlaksananya pratikum IPA dengan optimal karena ketersediaan sarana labor IPA masih kurang.

\section{KA IANTEORTIS}

Dalam Kamus Besar Bahasa Indonesia yang dimaksud dengan kontribusi adalah "masukan yang sangat berarti dari suatu aspek kepada aspek yang lain. Menurut

\section{4 | Jurnal al-Fikrah, Vol. VII, No. 1 Januari-Juni 2019}


Marshall dalam Sudarmanto (2009: 46) kompetensi adalah karakteristik dasar dari seseorang yang memungkinkannya memberikan kinerja unggul dalam pekerjaan, peran atau situasi tertentu. Menurut Musamus (2010: 421-429) Kompetensi manajerial kepala sekolah adalah kemampuan kepala sekolah dalam mendaya gunakan semua sumber daya sekolah untuk mencapai tujuan pendidikan disekolah. Menurut Wahjosumidjo (2002: 83) Kepala sekolah adalah seorang tenaga fungsional guru yang diberi tugas untuk memimpin suatu sekolah dimana diselenggarakan proses belajar mengajar, atau tempat dimana terjadi interaksi antara guru yang memberi pelajaran dan murid yang menerima pelajaran. Menurut Sujanto (2007: 61) Komite Sekolah adalah badan mandiri yang mewadahi peranserta masyarakat dalam rangka peningkatan mutu, pemerataan dan efisiensi pengelolaan pendidikan di satuan pendidikan, dibentuk berdasarkan musyawarah yang demokratis oleh stakeholder pendidikan.

Menurut Kertiasa (2006: 1) secara etimologi kata "laboratorium" berasal dari kata latin yang berarti "tempat bekerja" dan dalam perkembangannya kata "laboratorium" mempertahankan kata aslinya yaitu "tempat bekerja", akan tetapi khusus untuk keperluan penelitian ilmiah. Menurut W.J.S. Poerwadarminta, dalam Emha (2002: 6) mengatakan bahwa: Laboratorium adalah tempat untuk mengadakan percobaan (penyelidikan dan sebagainya) segala sesuatu yang berhubungan dengan ilmu fisika, kimia, dan sebagainya. Sedangkan laboran adalah orang (ahli ilmu kimia dan sebagainya) yang bekerja di laboratorium.

\section{METODOLOGOPENEUTAN}

Penelitian ini menggunakan pendekatan kuantitatif dengan rancangan korelasional karena dalam penelitian ini mencoba mengetahui hubungan yang ada, antar variabel yang dikorelasikan. Penelitian ini dilaksanakan pada SMPN di Kota Sawahlunto. Populasi 30 orang dengan teknik pengambilan sampel menggunakan total sampling, Teknik pengumpulan data dengan menggunakan Angket (Kuiseoner). Data penelitian ini dianalisis dengan menggunakan teknik korelasi dan regresi. Analisis data dilakukan dengan bantuan komputer program SPSS versi 17.

1. Pengujian Analisis

a. Uji Normalitas bertujuan untuk mengetahui apakah data yang terkumpul berdistribusi normal atau tidak. Dalam penelitian ini uji normalitas dapat digunakan uji Kolmogorov Smirnov, dengan hipotesis Ho:populasi berdistribusi normal, $\mathrm{H}_{1}$ : populasi tidak berdistribusi normal pada taraf nyata $\alpha=0,05$ atau signifikan $>0,05$

b. Uji Homogenitas pada penelitian ini menggunakan Chi-Square atau uji keselarasan dengan hipotesis $\mathrm{H}_{\mathrm{O}}$ : ragam sampel homogen, $\mathrm{H}_{1}$ : ragam sampel tidak homogen dengan kriteria pengujian $\mathrm{H}_{\mathrm{o}}$ diterima bila $\mathrm{X}_{\text {hit }}^{2} \quad \mathrm{X}^{2}$ tabel dengan taraf nyata $\alpha=0,05$

c. Uji linearitas antar variabel penelitian yang dilakukan untuk menentukan kelinearan antara variabel bebas dengan variabel terikat $(\mathrm{Y})$, dan antara variabel bebas $(\mathrm{X})$ dengan variabel terikat $(\mathrm{Y})$. Uji linieritas pada penelitian ini 
menggunakan ANOVA (analysis of variance) dan uji $\mathrm{F}$ dengan hipotesis $\mathrm{H}_{\mathrm{O}}$ : terdapat hubungan fungsioal linear, $\mathrm{H}_{1}$ tidak terdapat hubungan fungsional linear, dengan kriteria pengujian $\mathrm{Ho}$ diterima jika $\mathrm{F}$ hit $\mathrm{F}$ tabel dengan taraf nyata $\alpha=0,05$

\section{Pengujian Hipotesis}

a. Hipotesis 1 dan 2 diuji dengan menggunakan teknik korelasi dan regresi linear sederhana.

b. Hipotesis 3 diuji dengan menggunakan teknik korelasi dan regresi ganda. Untuk memerikasa peluang pengembangan prediksi secara kondisional menggunakan teknik korelasi parsial.

Pengujian untuk mengetahui tingkat pencapaian responden pada masing-masing variabel dengan menggunakan rumus:

$\begin{array}{lll}\text { Skor rata-rata } & \text { X 100\% } \\ \text { Skor maksimal } & \\ \text { Kategori nilai } & \text { menurut Sudjana }\end{array}$
(2004:142) yang dicapai oleh responden menggunakan klasifikasi sebagai berikut:

$$
\begin{array}{ll}
90-100 \% & =\text { sangat baik } \\
80-89 \% & =\text { baik } \\
65-79 \% & =\text { cukup } \\
55-64 \% & =\text { kurang baik } \\
0-54 \% & =\text { tidak baik }
\end{array}
$$

\section{HASIL PENEUTIANDANPEMBAHASAN}

Ketersediaan Sarana Labor IPA, Tingkat pencapaian skor Ketersediaan Sarana Labor IPA termasuk cukup (64,48\%). Hasil ini menunjukkan bahwa Ketersediaan Sarana Labor IPA tersebut termasuk kategori Kurang baik. Secara rinci dapat dijelaskan bahwa indikator pertama Ketersediaan Sarana Labor IPA adalah rasio bangunan labor dengan tingkat pencapaian ...indikator kedua perabot, dengan tingkat pencapaian 60,86\% atau Kurang, indikator ketiga peralatan pendidikan, dengan tingkat pencapaian $61,51 \%$ atau kurang, indikator keempat media pendidikan, dengan tingkat pencapaian $87,40 \%$ atau baik, dan indikator kelima adalah perlengkapan lain, dengan tingkat pencapaian 89,32\% atau baik.

Data variabel Manajerial kepala sekolah, tingkat pencapaian responden setiap indikator pada variabel Manajerial kepala sekolah Secara rinci dapat dijelaskan bahwa indikator pertama Manajerial kepala sekolah adalah Perencanaan, dengan tingkat pencapaian $61,33 \%$ atau cukup, indikator kedua mengelola sarana dan prasarana, degan tingkat pencapaian 58,00\% atau kurang, indikator ketiga mengelola keuangan, dengan tingkat pencapaian 54,47\% atau kurang, indikator keempat adalah Melakukan Monitoring evaluasi dan pelaporan, dengan tingkat pencapaian 64,30\% atau kurang.

Data variabel Peran Komite Sekolah diperoleh Secara rinci dapat dijelaskan bahwa indikator pertama Peran Komite Sekolah adalah badan penghubung, dengan tingkat pencapaian $63,27 \%$ atau kurang, indikator kedua Badan pendukung, degan tingkat pencapaian $65,77 \%$ atau baik, indikator ketiga Badan Pengontrol, dengan tingkat pencapaian 64,44\% atau cukup, dan indikator keempat adalah badan penghubung, dengan tingkat pencapaian $64,16 \%$ atau cukup.

\section{Temuan Penelitian}

Berdasarkan hasil analisis deskripsi data dan tingkat pencapaian responden terhadap setiap variabel yang diukur, maka peneliti 
menemukan hasil penelitian di mana tingkat pencapaian responden tentang Ketersediaan Sarana Labor IPA ternyata 64,48\% (termasuk kategori Kurang baik), Manajerial Kepala Sekolah ternyata 60,92\% (termasuk kategori Kurang baik), dan Peran Komite Sekolah ternyata $64,27 \%$ (termasuk kategori kurang baik).

Hasil analisis data dan pengujian hipotesis menunjukkan bahwa ketiga hipotesis telah teruji secara empiris. Dari hasil analisi data menunjukkan bahwa Manajerial kepala sekolah dan Peran Komite Sekolah baik secara sendiri-sendiri maupun secara bersama-sama memiliki kontribusi yang berarti dengan Ketersediaan Sarana Labor IPA. Adapun besarnya kontribusi Manajerial kepala sekolah terhadap Ketersediaan Sarana Labor IPA adalah 27,1\%, kontribusi Peran Komite Sekolah terhadap Ketersediaan Sarana Labor IPA adalah $26,2 \%$, dan apabila secara bersamasama Manajerial kepala sekolah dan Peran Komite Sekolah terhadap Ketersediaan Sarana Labor IPA secara secara bersama sama memiliki kontribusi yang berarti yakni sebesar 39,5\%.

\section{Pembahasan}

Berdasarkan penelitian yang telah dilakukan, maka peneliti akan membahas satu persatu tentang hasil penelitian terhadap ketiga variabel dalam penelitian ini yaitu variabel Ketersediaan sarana labor IPA dengan lima indikator, variabel Kompetnsi manajerial kepala sekolah dengan empat indikator dan Peran komite sekolah dengan empat indikator.

Tabel 16. Tingkat Pencapaian Responden setiap variabel dan indikator

\begin{tabular}{|c|c|c|c|c|c|}
\hline Variabel & Indikator & $\begin{array}{l}\text { Skor } \\
\text { ideal }\end{array}$ & Rata-rata & \begin{tabular}{|c|}
$\%$ tingkat \\
pencapaian
\end{tabular} & Kategori \\
\hline \multirow{5}{*}{$\begin{array}{l}\text { I. Ketersediaan } \\
\text { sarana labor } \\
\text { IPA }\end{array}$} & a. Rasio bangunan & 10 & 4,43 & 60,86 & Kurang \\
\hline & b. Perabot & 35 & 21,3 & 60,86 & Kurang \\
\hline & $\begin{array}{l}\text { c. Peralatan } \\
\text { Pendidikan }\end{array}$ & 205 & 126,10 & 61,51 & Kurang \\
\hline & d. Media Pendidikan & 5 & 4,37 & 87,40 & Baik \\
\hline & e. Perlengkapan Lain & 25 & 22,33 & 89,32 & Baik \\
\hline \multicolumn{2}{|c|}{$\begin{array}{l}\text { Keseluruhan indikator variabel } \\
\text { Ketersediaan sarana labor IPA }\end{array}$} & 270 & 174,10 & 64,48 & Kurang \\
\hline \multirow{3}{*}{$\begin{array}{l}\text { II. Kompetensi } \\
\text { Manajerial } \\
\text { Kepala } \\
\text { sekolah }\end{array}$} & a. Perencanaan & 45 & 27,6 & 61,33 & Kurang \\
\hline & 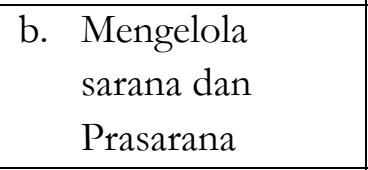 & 20 & 11,6 & 58,00 & Kurang \\
\hline & $\begin{array}{l}\text { c. Mengelola } \\
\text { Keuangan }\end{array}$ & 15 & 8,17 & 54,47 & Kurang \\
\hline
\end{tabular}




\begin{tabular}{|c|c|c|c|c|c|}
\hline & $\begin{array}{ll}\text { d. } & \text { Melakukan } \\
& \text { Monitoring } \\
\text { evaluasi dan } \\
\text { pelaporan }\end{array}$ & 10 & 6,43 & 64,30 & Kurang \\
\hline \multicolumn{2}{|c|}{$\begin{array}{l}\text { Keseluruhan indikator variabel } \\
\text { Kompetensi manajerial }\end{array}$} & 90 & 53,8 & 59,78 & cukup \\
\hline \multirow{4}{*}{$\begin{array}{l}\text { III. Peran komite } \\
\text { sekolah }\end{array}$} & $\begin{array}{l}\text { a. Badan } \\
\text { Pertimbangan }\end{array}$ & 55 & 34,8 & 63,27 & cukup \\
\hline & $\begin{array}{l}\text { b. Badan } \\
\text { Pendukung }\end{array}$ & 30 & 19,73 & 65,77 & Baik \\
\hline & $\begin{array}{l}\text { c. Badan } \\
\text { Pengontrol }\end{array}$ & 90 & 58 & 64,44 & cukup \\
\hline & $\begin{array}{ll}\text { d. } & \text { Badan } \\
& \text { Penghubung }\end{array}$ & 45 & 28,87 & 64,16 & cukup \\
\hline \multicolumn{2}{|c|}{$\begin{array}{l}\text { Keseluruhan indikator variabel Peran } \\
\text { komite sekolah }\end{array}$} & 220 & 141,4 & 64,27 & kurang \\
\hline
\end{tabular}

Menurut hasil penelitian yang penulis lakukan terhadap Ketersediaan Sarana Labor IPA, kondisi aktualnya secara umum kondisinya tergolong kurang baik (64,48\%). Ditemukan bahwa tingkat pencapaian skor keseluruhan Ketersediaan Sarana Labor IPA termasuk kurang. Hasil ini menunjukkan bahwa Ketersediaan Sarana Labor IPA belum optimal sesuai dengan yang diharapkan.

Secara perindikator diketahui bahwa Ketersediaan Sarana Labor IPA dengan tingkat pencapaian responden pada indikator rasio bangunan labor berada pada posisi kurang berarti rasio bangunan labor IPA kurang baik perabot berada pada posisi kurang, ini berarti perabot labor IPA masih kurang baik (60,86\%), indikator Peralatan Pendidikan, hanya mencapai $(61,51 \%)$ dalam artian kurang baik, indikator Media Pendidikan berada pada posisi baik (87,40\%), dan Perlengkapan Lain berada pada posisi baik $(89,32 \%)$.

\section{8 | Jurnal al-Fikrah, Vol. VII, No. 1 Januari-Juni 2019}

Sebagaimana dijelaskan dalam teori Ketersediaan Sarana Labor IPA bahwa Ketersediaan Sarana Labor IPA adalah bagaimana perabot yang dimiliki, peralatan pendidikan, media pendidikan dan perlengkapan lain yang musti di sediakan oleh labor suatu sekolah tersebut. Melihat data - data penelitian tentang Ketersediaan Sarana Labor IPA, tergambar bahwa Ketersediaan Sarana Labor IPA kurang baik, dengan demikian Ketersediaan Sarana Labor IPA perlu ditingkatkan lagi agar bisa mencapai kearah yang baik.

Secara operasional Kompetensi manajerial kepala sekolah dalam penelitian ini didefenisikan adalah kompetensi manajerial kepala sekolah dalam melengkapi ketersediaan sarana Labor IPA di SMP Negeri di kota Sawahlunto.

Adapun indikator yang dijadikan untuk mengetahui kemampuan manajerial kepala sekolah adalah: 
a) Kemampuan menyusun perencanaan sekolah/madrasah untuk berbagai tingkatan perencanaan;

b) Kemampuan mengelola sarana dan prasarana sekolah/madrasah dalam rangka pendayagunaan secara optimal;

c) Kemampuan untuk mengelola keuangan sekolah/madrasah sesuai dengan prinsip pengelolaan yang akuntabel, transparan, dan efisien;

d) Kemampuan melakukan monitoring, evaluasi, dan pelaporan pelaksanaan program kegiatan sekolah/madrasah dengan prosedur yang tepat, serta merencanakan tindak lanjutnya

Berdasarkan hasil analisis deskripsi data tentang tingkat pencapaian indikator Manajerial kepala sekolah hasilnya sebagai berikut:

Menurut hasil penelitian yang penulis lakukan kondisi aktual Manajerial kepala sekolah ternyata secara umum kondisinya tergolong kurang baik (60,92\%). Dengan demikian, secara umum Manajerial kepala sekolah kurang baik dalam (1) Membuat perencanaa sekolah/madrasah untuk berbagai tingkatan perencanaan, (2) Mengelola sarana dan Prasarana sekolah/madrasah dalam rangka pendayagunaan secara optimal, (3) Mengelola Keuangan sekolah/madrasah sesuai dengan prinsip pengelolaan yang akuntabel, transparan, dan efisien dan (4) Melakukan Monitoring evaluasi dan pelaporan pelaksanaan program kegiatan sekolah/madrasah dengan prosedur yang tepat, serta merencanakan tindak lanjutnya.

Secara operasional Peran Komite Sekolah dalam penelitian ini didefenisikan adalah badan mandiri yang mewadahi peran serta masyarakat dalam rangka peningkatan mutu, pemerataan dan efisiensi pengelolaan pendidikan di satuan pendidikan, dibentuk berdasarkan musyawarah yang demokratis oleh stakeholder pendidikan.

Indikator yang dijadikan untuk mengetahui peran Komite Sekolah adalah:

a) Pemberi pertimbangan (advisory agency) dalam penentuan dan pelaksanaan kebijakan pada sarana prasarana labor IPA.

b) Pendukung (supporting agenc) dalam pengadaan sarana prasarana labor IPA.

c) Pengontrol (controling agency) dalam rangka transparansi dan akuntabilitas dalam penyediaan sarana prasarana labor IPA.

d) Mediator antara pemerintah (executive) dengan masyarakat, orang tua murid dan masyarakat terhadap ketersediaan sarana prasarana labor IPA.

Menurut hasil penelitian yang penulis lakukan kondisi aktual Peran Komite Sekolah ternyata secara umum kondisinya tergolong kurang baik (64,27\%). Dengan demikian, secara umum Peran Komite Sekolah kurang baik dalam (1), Pemberi pertimbangan (advisory agency) dalam penentuan dan pelaksanaan kebijakan pada sarana prasarana labor IPA (2) Pendukung (supporting agenc) dalam pengadaan sarana prasarana labor IPA, (3) engontrol (controling agency) dalam rangka transparansi dan akuntabilitas dalam penyediaan sarana prasarana labor IPA dan (4) Mediator antara pemerintah (executive) dengan masyarakat, orang tua murid dan masyarakat terhadap ketersediaan sarana labor IPA.

Kontribusi Manajerial kepala sekolah dengan Ketersediaan Sarana Labor IPA. Setelah dilakukan pengkajian mendalam melalui proses analisis di atas, maka diyakini 
bahwa hipotesis penelitian yang menyatakan "Manajerial kepala sekolah berkontribusi terhadap Ketersediaan Sarana Labor IPA" dapat diterima dan telah teruji pada tarap kepercayaan 95\%. Selanjutnya dapat diinterprentasikan bahwa Manajerial kepala sekolah memiliki kontribusi positif dan signifikan terhadap Ketersediaan Sarana Labor IPA sebesar 27,1\%. Hal ini menunjukkan bahwa 27,1\% keberhasilan Ketersediaan Sarana Labor IPA ditentukan oleh Manajerial kepala sekolah.

Kepala sekolah dalam menyusun perencanaan sekolah/madrasah untuk berbagai tingkatan perencanaan, mengelola sarana dan prasarana sekolah/madrasah dalam rangka pendayagunaan secara optimal, untuk mengelola keuangan sekolah/madrasah sesuai dengan prinsip pengelolaan yang akuntabel, transparan, dan efisien ternyata, melakukan monitoring, evaluasi, dan pelaporan pelaksanaan program kegiatan sekolah/madrasah dengan prosedur yang tepat, serta merencanakan tindak lanjutnya dimana setiap kepala sekolah mengambil langkah-langkah yang menyangkut dengan sikap manajerialnya berkontribusi terhadap bagaimana perabot yang dimiliki, peralatan pendidikan, media pendidikan dan perlengkapan lain yang musti di sediakan oleh labor suatu sekolah tersebut.

Melihat data-data penelitian tentang Ketersediaan Sarana Labor IPA, tergambar bahwa Ketersediaan Sarana Labor IPA kurang baik, dengan demikian Ketersediaan Sarana Labor IPA perlu ditingkatkan lagi agar bisa mencapai kearah yang baik, Ketersediaan Sarana Labor IPA bagaimana perabot yang dimiliki, peralatan pendidikan, media pendidikan dan perlengkapan lain

\section{Jurnal al-Fikrah, Vol. VII, No. 1 Januari-Juni 2019}

yang musti disediakan oleh labor suatu sekolah tersebut.

Kontribusi Peran Komite Sekolah terhadap Ketersediaan Sarana Labor IPA. Komite Sekolah yang mampu mewadahi peran serta masyarakat dalam rangka peningkatan mutu, pemerataan dan efisiensi pengelolaan pendidikan di satuan pendidikan, maka akan berkontribusi terhadap Ketersediaan Sarana Labor IPA pada suatu satuan pendidikan.

Komite Sekolah yang mempunyai kemampuan / kesanggupan yang tinggi akan mempunyai kontribusi terhadap Ketersediaan Sarana Labor IPA yang baik pula. Kerena dengan kemampuan yang dimiliki akan dapat melaksanakan perannya sendiri dengan baik pula.

Sebagai pemberi pertimbangan, pendukung, pengontrol dan mediator dengan pemerintah dan masyarakat dalam penentuan dan pelaksanaan kebijakan untuk melengkapi sarana dan prasarana Ketersediaan Sarana Labor IPA. Dengan demikian pertimbangan, pendukung, pengontrol dan mediator yang diberikan akan membuat seluruh komponen yang menyangkut dengan Ketersediaan Sarana Labor IPA dapat dipenuhi dengan baik.

Dengan demikian dapat dikatakan bahwa Ketersediaan Sarana Labor IPA akan dapat terpenuhi bila Peran Komite Sekolah pada suatu sekolah berjalan dengan baik dan semestinya. Menurut Sujanto (2007: 61) secara teoritis peran Komite Sekolah adalah “...badan mandiri yang mewadahi peranserta masyarakat dalam rangka peningkatan mutu, pemerataan dan efisiensi pengelolaan pendidikan di satuan pendidikan, dibentuk berdasarkan musyawarah yang demokratis oleh stakeholder pendidikan. 
Dalam hal ini peran yang dijalankan Komite Sekolah Sekolah adalah sebagai berikut: Pemberi pertimbangan (advisory agency) dalam penentuan dan pelaksanaan kebijakan pendidikan di satuan pendidikan, Pendukung (supporting agency), baik yang berwujud finansial, pemikiran, maupun tenaga dalam penyelenggaraan pendidikan di satuan pendidikan, Pengontrol (controlling agency) dalam penyelenggaraan kegiatan di satuan pendidikan dan sebagai Mediator antara pemerintah (eksekutif) dengan masyarakat di satuan pendidikan. Dalam analisis data tergambar bahwa tingkat pencapaian responden terhadap variabel peran Komite Sekolah adalah 64,27\% atau kurang.

Sesuai dengan hipotesis yang di nyatakan "Peran Komite Sekolah berkontribusi yang positif dan signifikan terhadap Ketersediaan Sarana Labor IPA" dapat diterima dan telah teruji pada tarap kepercayaan 95\%. Selanjutnya dapat diinterprentasikan bahwa Peran Komite Sekolah memiliki berkontribusi sangat signifikan terhadap Ketersediaan Sarana Labor IPA sebesar 26,2\%. Hal ini menunjukkan bahwa 26,2\% keberhasilan Ketersediaan Sarana Labor IPA ditentukan oleh Peran Komite Sekolah.

Kontribusi Manajerial kepala sekolah dan Peran Komite Sekolah secara bersama sama terhadap Ketersediaan Sarana Labor IPA. Manajerial kepala sekolah yang digunakan merupakan salah satu kunci keberhasilan pelaksanaan program pada suatu Sekolah . Manajerial kepala sekolah diperkirakan berkontribusi terhadap Peran Komite Sekolah yang ada pada satuan pendidikan. Perencanaan, pengelolaan sarana dan prasarana, mengelola keuangan dan Melakukan Monitoring evaluasi dan pelaporan akan muncul apabila peran Komite Sekolah sekolah bersifat mendukung setiap aktivitas sehingga memperlancar proses membenahi dan memperbaiki serta melengkapi seluruh fasilitas labor IPA pada satuan pendidikan yang dibawahinya.

Manajerial kepala sekolah dan Peran Komite Sekolah secara bersama-sama diperkirakan berkontribusi terhadap Ketersediaan Sarana Labor IPA di SMPN yang ada di Sawahlunto. Untuk mengetahui bagaimana kontribusi Manajerial kepala sekolah dan Peran Komite Sekolah secara bersama-sama terhadap Ketersediaan Sarana Labor IPA, maka ditawarkan hipotesis "Manajerial kepala sekolah dan Peran Komite Sekolah secara bersama-sama berkontribusi yang positif dan signifikan terhadap Ketersediaan Sarana Labor IPA". dapat diterima dan telah teruji pada tarap kepercayaan 95\%. Selanjutnya dapat diinterprentasikan bahwa Manajerial kepala sekolah dan Peran Komite Sekolah memiliki kontribusi yang positif dan signifikan terhadap Ketersediaan Sarana Labor IPA sebesar 39,5\%. Hal ini menunjukkan bahwa $39,5 \%$ Ketersediaan Sarana Labor IPA ditentukan oleh Manajerial kepala sekolah dan Peran Komite Sekolah. Dengan kata lain secara simultan kedua faktor tersebut mempunyai kontribusi dengan Ketersediaan Sarana Labor IPA.

Dengan menggunakan analisis korelasi dan regresi berganda antara variabel bebas Manajerial Kepala Sekolah $\left(\mathrm{X}_{1}\right)$ dan Peran Komite Sekolah $\left(X_{2}\right)$ dengan variabel terikat Ketersediaan Sarana Labor IPA (Y) dapat diketahui besarnya koefisien korelasi Ry.1.2 $=0.629$ dan koefisien determinasi sebesar $\mathrm{R}^{2} \mathrm{y} \cdot 1.2=0.395$. Dapat disimpulkan bahwa $39,5 \%$ variasi yang terjadi pada variabel Ketersediaan Sarana Labor IPA disebabkan 
oleh kedua variabel bebas Manajerial kepala sekolah dan Peran Komite Sekolah, sementara sisanya $60,5 \%$ disebabkan oleh faktor lain di luar variabel yang diteliti.

Setelah dilakukan pengujian secara statistik ternyata persamaan regresi yang diperoleh merupakan model yang baik untuk memperkirakan tingkat Ketersediaan Sarana Labor IPA. Dengan demikian terdapat kontribusi yang positif dan linear masingmasing variabel yang digunakan dalam penelitian.

Untuk memperjelas gambaran kontribusi Kompetensi manajerial kepala sekolah dan peran komite terhadap ketersediaan sarana Labor IPA di SMPN kota Sawahlunto, maka di bawah ini dapat dilihat pada tabel berikut:

Tabel 31. Rangkuman Kontribusi antar Variabel

\begin{tabular}{|c|c|c|c|c|c|}
\hline $\mathrm{NO}$ & Variabel & Indikator & $\begin{array}{l}\% \text { Tingkat } \\
\text { Pencapaian }\end{array}$ & $\begin{array}{c}\% \\
\text { Kontribusi } \\
\text { kpd Labor }\end{array}$ & Ket \\
\hline \multirow{4}{*}{1} & \multirow{4}{*}{$\begin{array}{c}\text { Kompetensi } \\
\text { Manajerial } \\
\text { Kepala } \\
\text { Sekolah }\end{array}$} & a. Perencanaan & 61,33 & 16,62 & Kurang \\
\hline & & $\begin{array}{l}\text { b. Mengelola sarana dan } \\
\text { Prasarana }\end{array}$ & 58 & 15,72 & Kurang \\
\hline & & c. Mengelola Keuangan & 54,47 & 14,76 & Kurang \\
\hline & & $\begin{array}{l}\text { d. Melakukan Monitoring } \\
\text { evaluasi dan pelaporan }\end{array}$ & 64,3 & 17,43 & Cukup \\
\hline \multirow{4}{*}{2} & \multirow{4}{*}{ Peran Komite } & a. Badan Pertimbangan & 63,27 & 16,58 & cukup \\
\hline & & b. Badan Pendukung & 65,77 & 17,23 & Baik \\
\hline & & c. Badan Pengontrol & 64,44 & 16,88 & cukup \\
\hline & & d. Badan Penghubung & 64,16 & 16,81 & cukup \\
\hline
\end{tabular}

Tabel di atas menggambarkan bahwa kontribusi Kompetensi manajerial kepala sekolah terhadap ketersediaan sarana labor IPA, hanya indikator Melakukan Monitoring evaluasi dan pelaporan yang mencapai baik atau $64,30 \%$ sementara tiga indikator lainnya seperti Mengelola sarana dan Prasarana, Perencanaan, Mengelola Keuangan berada pada posisi kurang berkontribusi dalam penyediaan sarana Labor IPA.

Kontribusi variabel peran Komite terhadap ketersediaan sarana labor IPA tiga indikatornya masih berada pada kategori cukup yakni, Badan Pertimbangan (63,27\%), Badan Pengontrol (64,44\%), Badan Peng- hubung $(64,16 \%)$ dan hanya indikator Badan Pendukung yang memiliki kategori baik dalam kontribusinya terhadap ketersediaan sarana labor IPA yakni (65,77\%).

\section{Kesimpulan}

Kontribusi yang positif dan signifikan antara kompetensi manajerial kepala sekolah dan peran komite sekolah terhadap ketersediaan sarana labor IPA pada SMPN di-kota Sawahlunto sebagai berikut:

Kompetensi Manajerial kepala sekolah berkontribusi yang positif dan signifikan terhadap Ketersediaan Sarana Labor IPA sebesar 27,1\%. Peran Komite Sekolah

\section{Jurnal al-Fikrah, Vol. VII, No. 1 Januari-Juni 2019}


berkontribusi yang positif dan signifikan terhadap Ketersediaan Sarana Labor IPA sebesar 26,2\%. Manajerial kepala sekolah dan Peran Komite Sekolah secara bersama - sama (simultan) berkontribusi yang positif dan signifikan terhadap Ketersediaan Sarana Labor IPA sebesar 39,5\%.

\section{Implikasi Hasil Penelitian}

Hasil yang diperoleh melalui penelitian ini memberikan beberapa implikasi secara keilmuan:

1. Terhadap kepala sekolah. Sebagai manajer pendidikan pada tingkat satuan pendidikan, kepala sekolah dituntut agar mampu mengelola sumber daya sekolah secara efektif dan efesien. Dengan hasil penelitian kecenderungannya kurang berimplikasi bahwa kepala sekolah perlu meningkatkan kompetensinya. Hal ini menuntut kepala sekolah untuk terus meningkatkan kompetensinya secara keseluruhan terutama dalam kompetensi manajerial.

2. Terhadap komite sekolah. Peran komite sekolah berorientasi kepada berbagai kewenangan pengguna, dan kemitraan yang difokuskan kepada ketersediaan sarana labor IPA. Dengan hasil penelitian kecenderungan kurang, maka memberikan implikasi bahwa perlu memberikan pengetahuan, melatih keterampilan dan memberikan motivasi kerja kepada seluruh personil komite sekolah agar mereka dapat menjalankan peran dan fungsinya secara optimal. Dengan demikian maka sarana labor IPA akan dapat terpenuhi sesuai ketentuan.

3. Terhadap pengambil keputusan/ Pemerintah. Sarana labor IPA merupakan hal yang sangat penting untuk disediakan secara lengkap, agar kegiatan pembelajaran IPA bisa berlangsung dengan baik. Dengan hasil penelitian kecenderungan kurang maka memberikan implikasi bahwa sarana labor IPA perlu dilengkapi agar proses belajar mangajar atau praktek dapat berlangsung dengan lancar.

\section{Saran-saran}

Setelah mengkaji permasalahan yang dimunculkan dalam penelitian, maka dipandang perlu mengajukan saran-saran yang bermamfa'at bagi berbagai pihak, yaitu;

1. Bagi Kepala Sekolah

Dengan hasil penelitian yang kecenderungannya kurang bukan berarti kepala sekolah tidak mempunyai kemampuan. Adapun saran yang penulis berikan adalah:

a. Kepala sekolah agar senantiasa memenuhi kompetensi manajerialnya secara utuh.

b. Kepala sekolah hendaknya senantiasa mengembangkan diri dalam aspek manajemen untuk mewujudkan sekolah efektif dan terpenuhinya sarana labor IPA.

c. Kepala sekolah secara efektif mampu menyerap dan menggunakan sumber daya pengetahuan yang dimiliki pendidik dan tenaga kependidikan.

2. Bagi Komite Sekolah.

Dengan hasil penelitian kecenderungan kurang peran komite perlu dioptimalkan.

a. Pemberian pertimbangan dalam penentuan kebijakan pendidikan di sekolah, agar sarana prasarana sekolah dapat dilengkapi, sehingga sarana 
labor IPA dapat tersedia sesuai dengan ketentuan.

b. Mendukung penyelenggaraan pendidikan disekolah dalam bentuk biaya, tenaga dan pemikiran agar kekurangan rasio bangunan labor, perabot dan alat pendidikan labor IPA dapat dilengkapi.

c. Mengontrol penyelenggaraan dan keluaran pendidikan dalam rangka tranparansi dan akuntabilitas.

d. Mediator antara pemerintah dan masyarakat, komite sekolah harus mampu menyalurkan aspirasi yang berkembang di masyarakat yang berorientasi pada kemajuan sekolah.

\section{KEPUSTAKAANACUAN}

Kep Mendiknas, Nomor 004/U/ 2002 tanggal 2 April 2002.

Depdiknas, 2002: 26

Ibrahim Bafadal. 2006. Tugas Pokok dan Fungsi Kepala Sekolah: Materi Peningkatan Keterampilan Manajerial Kepala Sekolah. Jakarta: Depdiknas.

Bedjo Sujanto, 2007. Manajemen Pendidikan Berbasis Sekolab; Model Pengelolaan Sekolah Di Era Otonomi, Sagung Seto, Jakarta, Cet. 1.
Departemen Pendidikan dan Kebudayaan, 1996. Kamus Besar Bahasa Indonesia. Balai Pustaka, Jakarta.

Sudarmanto, 2009. Kinerja dan Pengembangan Kompetensi SDM , Jogjakarta, Pustaka Pelajar.

Basilius Redan Musamus Merauke, Pengarub Keterampilan manajerial Kepala Sekolah dan status sosial guru terhadap kinerja guru SMA Negeri I Merauke Papua, Jurnal Aplikasi Mana jemen ,Vo. 8, No. 2, Mei 2010, hlm. 421429: Mei 2010: vol 8 : no. 2: 424

Wahjosumidjo, 2002. Kepemimpinan Kepala Sekolah Tinjauan Teoritik dan Permasalabnnya, Jakarta: PT. Rajagrafindo Persada.

Bedjo Sujanto, Manajemen Pendidikan Berbasis Sekolah; Model Pengelolaan Sekolah Di Era Otonomi, Sagung Seto, Jakarta, Cet. 1, 2007.

Nana Sujana, Ibrahim, 2004. Penelitian dan penilaian pendidikan Bandung: Sinar Baru Algesindo.

Nyoman Kertiasa, 2006. Laboratorium Sekolah dan Pengelolaannya, Bandung: Pudak Scientific.

Saleh H. Emha, dkk, 2002. Pedoman Penggunaan Laboratorium Sekolah, Bandung: PT Remaja Rosdakarya. 